Instructions for authors, subscriptions and further details:

http://brac.hipatiapress.com

\title{
Auriga y mis Juguetes de Piedra: Una Aventura Escultórica entre Arte y Juego. In Memoriam Benjamín Martino
}

Oriol Vaz-Romero Trueba ${ }^{1}$

1) Universitat de Barcelona. España

Date of publication: October 3rd, 2015

Edition period: October 2015 - February 2016

To cite this article: Vaz-Romero, O. (2015). Auriga y mis juguetes de piedra: una aventura escultórica entre arte y juego. In memoriam Benjamín Martino. Barcelona, Research, Art, Creation, 3(3), 277-308. doi: 10.17583/ brac. 2015.1562

To link this article: http://dx.doi.org/10.17583/brac.2015.1562

\section{PLEASE SCROLL DOWN FOR ARTICLE}

The terms and conditions of use, except where otherwise noted, are related to the Open Journal System and to Creative Commons Attribution License (CCBY). The indication must be expressly stated when necessary. 
BRAC - Barcelona Research Art Creation. Vol. 3 No. 3, October 2015, pp. 277-308

\section{Auriga and my Stone Toys. A Sculptural Experience between Art and Play. In Memoriam Benjamín Martino}

Oriol Vaz-Romero Trueba

University of Barcelona

(Received: 6 June 2015; Accepted: 29 August 2015; Published: 3 October 2015)

\section{Abstract}

These pages are dedicated to the memory of the Spanish artisan Benjamín Martino Martino (1935-2010), in order to reveal the creative process of my sculptures made out of iron and stones. We intend to inquire how far the poetic experience can be constructed in a distinctive way of knowledge, bringing together some unpublished sketches, pictures and writings from several travel books. For this purpose we have tried to give an order to the creative stages leading to both the confection of the public sculpture Auriga (2004) and the current series of Sibyls, consisting of fifty "toys" assembled with small stones from Etruscan lands. Linking the artist's intuition with the humanist's analytical language, we will explore the bounds between Art, Play and Myth, the three main components of the works here treated. In this research, the wonder is also presented as the pristine mechanism of the creative impulse of the artist, the child and mythopoiesis - present in the archaic cultures' meta-narratives-. Therefore, the sense of wonder does not lead to the suspension of human mind but to a strong motion of the imagination. This last is the child's natural condition that the adult poet must fight to regain, considering perchance in wonder remains hidden what Stefan Zweig describes as "the secret of artistic creation."

Keywords: Sculpture, Autobiography, Art Toys, Wonder, Game, Myth 
BRAC - Barcelona Research Art Creation. Vol. 3 No. 3, October 2015, pp. 277-308

\section{Auriga y mis Juguetes de Piedra: Una Aventura} Escultórica entre Arte y Juego. In Memoriam Benjamín Martino

Oriol Vaz-Romero Trueba Universidad de Barcelona

(Recibido: 6 Junio 2015; Aceptado: 29 Agosto 2015; Publicado: 3 Octubre 2015)

\section{Resumen}

Estas páginas, dedicadas a la memoria del forjador Benjamín Martino Martino (19352010), desvelan el proceso creativo de mis figuras de hierro y piedra. Entrelazando un conjunto inédito de bocetos, fotografías y anotaciones extraídas de varios cuadernos de viaje, nos proponemos inquirir hasta qué punto la experiencia poética puede erigirse en un modo singular de conocimiento. Para este fin, hemos tratado de ordenar las etapas que marcaron la construcción de la escultura pública Auriga (2004) y la actual serie de Sibilas, formada por cincuenta "juguetes" de piedras etruscas. Tratando de articular la intuición del artista con el lenguaje analítico del humanista, exploraremos la frontera entre arte, juego y mito, los tres componentes principales de las obras aquí tratadas. En esta investigación, el asombro se presenta además como el mecanismo prístino del impulso creador del artista, del niño y de la mitopoyética, constitutiva de los grandes relatos de las culturas arcaicas. Así pues, el asombro no es suspensión de la mente, sino (con)moción de la imaginación, estado natural en el que el niño habita y que el adulto debe reconquistar con esfuerzo, pues en esa experiencia de asombro se esconde acaso lo que Stefan Zweig llamó el "misterio de la creación artística".

Palabras clave: Escultura, Autobiografía, Juguetes de artista, Asombro, Juego, Mito

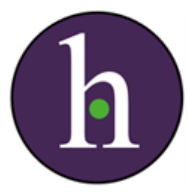




\section{${ }^{66} \mathrm{~N}$}

o sería más fácil probar, mediante una comparación filosófica entre las creaciones del artista maduro y el estado de su alma cuando era niño, que el genio no es sino la infancia netamente formulada, dotada ahora [...] de órganos fortalecidos?" Charles Baudelaire (1980: 293).

\section{La Figura del Artista "Binocular"}

Más de diez años han pasado desde que comencé a construir una familia de esculturas y "juguetes" con hierros y piedras. Desde el proyecto Auriga, en 2003, hasta la serie actual de Sibilas, estas piezas me han transportado a ese "genio de la infancia" que tanto había elogiado Baudelaire en sus Paradis Artificiels. Pero el poeta adviertía que no se trata de simular un estado pueril, sino de robustecer la antigua inocencia de la mirada con los nuevos "órganos" de la experiencia, que sólo el adulto posee. Sólo así la obra resultante logra trascender las despreocupadas fantasías del niño para situarnos en la encrucijada del Arte y las Humanidades. Me refiero a poder hacer de la vivencia artística un instrumento académico. He aquí la precisa cuestión que quisiera someter a análisis en estas páginas, tomando como referencia el proceso creativo de mis "juguetes de artista".

Sin olvidar la distancia que separa ambas realidades, la teorética y la estrictamente creativa, escribo pensando en nuestros alumnos de Bellas Artes y, con más motivo, en todos aquellos que se encuentran ante el reto de realizar investigaciones escritas a partir de su propia obra plástica. Dicha tarea consistiría en "propiciar la creación de un cuerpo teórico desde la experimentación, actuando así como contrapunto y complemento de la especulación pura y, por ende, de gran parte de la investigación universitaria tradicional" (Quílez Bach, 1990: 186). Sin duda, éste sigue siendo un camino apenas explorado en el actual Espacio Europeo de Enseñanza Superior. El artista ayudaría así a desvelar aquello que su obra "delata pero no exhibe" (Panofsky, 1955: 14). En este sentido, para interpretar mejor las etapas y el resultado final alcanzado, sería útil saber cómo una pintura, una escultura o un largometraje de animación vienen al mundo. Al proclamar que "el arte no puede enseñarse, pero ciertamente puede aprenderse " ", el 
propio Eduardo Chillida estaba sugiriendo que la experiencia artística constituye en sí misma una forma irrepetible de abordar el mundo y que, por ende, implica una forma de conocimiento diferenciada — aunque no antitética - de la que aportan las Humanidades y las Ciencias experimentales.

A simple vista, resulta arriesgado poner palabras a aquello que acontece en ausencia de palabras, a cuanto se manifiesta como acto puro. Quizá tuvo razón el historiador del arte Max Jakob Friedländer al sostener que "el artista creador debe ser rechazado como juez, porque [...] el saber destruye la capacidad de crear o, por lo menos, la quebranta" (1969: 113). Sin embargo la severidad de este alegato tropieza con el intento de no pocos artistas por razonar el acto poiético que brota de su imaginación. Se impone recordar aquí los textos de Giotto, Leonardo y Durero, los de Cennini y Miguel Ángel, también en España los de Francisco Pacheco y Antonio Palomino. Pero sólo en el siglo XX se agolpan a cientos los llamados "escritos de artista", algunos tan aclamados como los de Kandinsky, Matisse, Mondrian, Klee, Arp, Le Corbusier, Tàpies, Judd, Serra y Hockney. A todos ellos les embargaba el deseo de revelar mediante su experiencia personal aquello que Stefan Zweig definió como el misterio de la creación artística: "Tan imposible nos resulta explicar el elemento prístino de la fuerza creadora, como en el fondo nos es imposible decir qué es la electricidad o la fuerza de la gravitación o la energía magnética. [...] La solución ideal consistiría en que el artista nos expusiese el arcano de su creación en todas sus etapas y estados" (2007: 16-17), tratando de ordenar además los bocetos de sus obras, pues "estas son las únicas huellas visibles, el hilo de Ariadna que nos permite encontrar nuestro camino de regreso en ese laberinto misterioso" (2007: 26).

Enarbolada por los pioneros del Romanticismo alemán, esta labor presupone a la práctica del arte no ya valores expresivos, sino también un potencial cognitivo; un conocimiento que debería poder ser objetivado con los mecanismos que nos brindan las Humanidades o "ciencias del espíritu" Geisteswissenschaften - Precisamente Wilhelm Dilthey, el forjador de este término, manifestaba con vehemencia que "ninguna cabeza científica podrá nunca agotar, ni ningún proceso de la ciencia alcanzar lo que el artista puede decir sobre el contenido de la vida. El arte es el órgano de la comprensión de la vida" (1990: 274). De ahí, por ejemplo, la prevalencia en Dilthey (1944: 224) y en la historiografía moderna del género autobiográfico sobre todas las otras fuentes escritas de conocimiento (Redlich, 1975; Rodríguez-Cascante, 2000). 


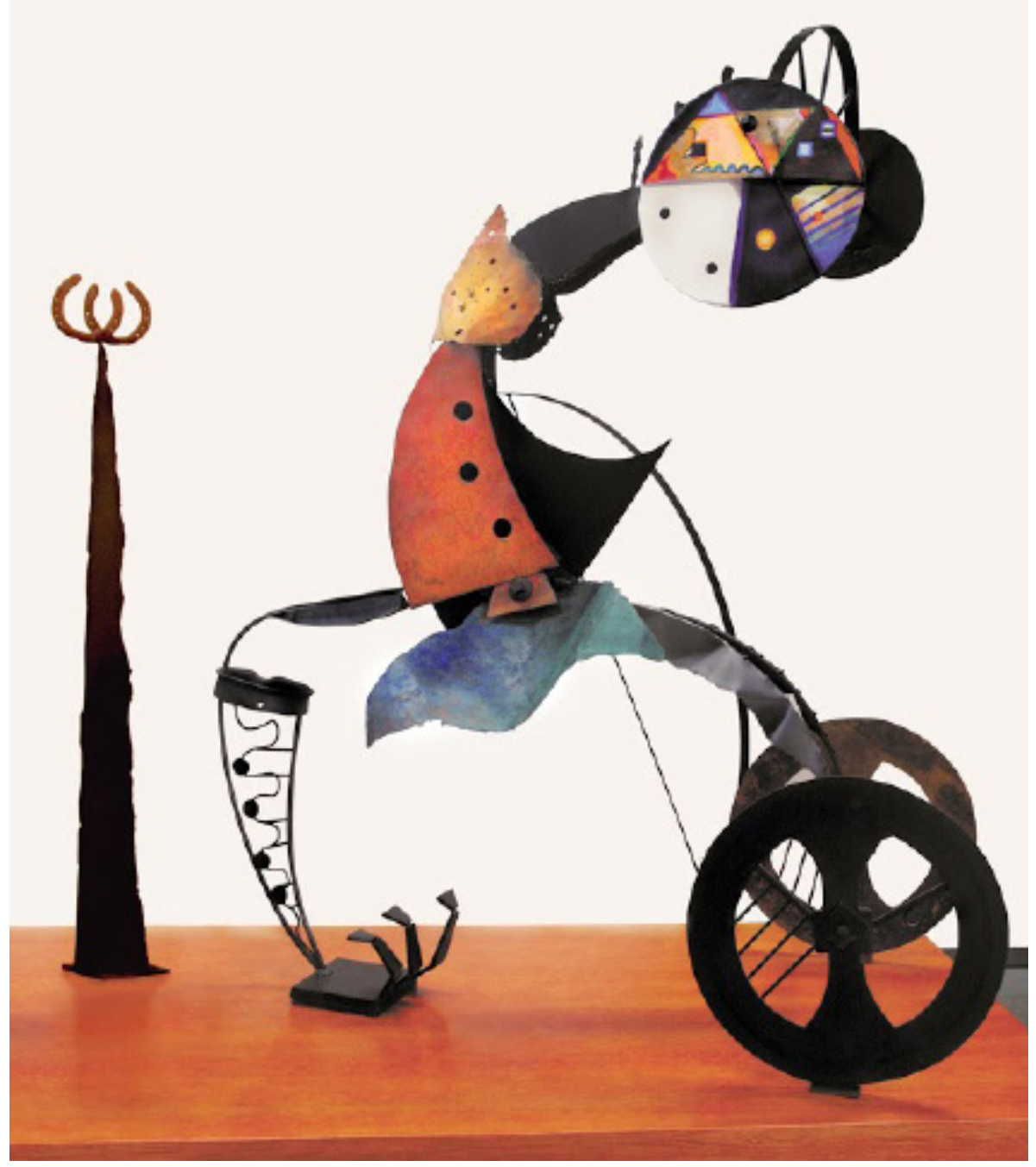

Figura 1. Oriol Vaz-Romero Trueba. Auriga, 2004. Hierro, terracota y pigmentos, 2.5 x 2.1 x 1.8 m. Barcelona, Clínica Sagrada Familia. 
Ahora bien, para llevar a buen puerto el cometido hermenéutico al que nos reta Stefan Zweig, debemos abandonar la excesiva parcelación, cuando no triste acuartelamiento, que sigue dominado los métodos de investigación académicos. Ya lo advertía Schiller en Über die ästhetische Erziehung des Menschen - 1795 - al comprender que el proyecto ilustrado europeo había "desgarrado la unidad interna de la naturaleza humana y una pugna fatal dividió sus armoniosas fuerzas. El entendimiento intuitivo [arte] y el especulativo [ciencia] se retiraron hostilmente a sus respectivos campos de acción, cuyas fronteras comenzaron a vigilar entonces desconfiados y recelosos". Sin encuentro entre disciplinas y metodologías, "la prolífica imaginación deseca los laboriosos plantíos del entendimiento" así como "el espíritu de abstracción consume la hoguera al lado de la cual habría podido calentarse el corazón y encenderse la fantasía" (2005: 147). En cierto modo, E. H. Gombrich, en su ya clásico Art and Illusion — 1960 — , rechazaba el mismo divorcio detectado por Schiller al considerar que "el modo como el lenguaje del arte se refiere al mundo visible es a la vez tan obvio y tan misterioso que todavía es desconocido en gran parte excepto por los artistas, que saben usarlo tal y como usamos todos los lenguajes, sin necesidad de conocer su gramática y su semántica". De ahí que un puente merezca ser tendido, expresa el historiador austríaco, "entre el campo de la historia del arte y el dominio del artista practicante" (1979: 23). Pero, ¿cómo podría trazarse un puente de esa índole?

Fue el profesor Elliot W. Eisner quien, a finales de los '70, defendió el retorno a una "binocularidad" investigadora, es decir, a un pensamiento híbrido liberado de los antiguos monismos metodológicos (Eisner, 1979). Refiriéndose a la educación artística, abogaba por fiarse de la experiencia poética, que es intrínsecamente intuitiva, no como rechazo de lo científico, sino más bien para hacer de dicha experiencia un punto de partida para construir una investigación más certera, pues "mirando a través de un solo ojo nunca proporcionaremos mucha profundidad de campo" (Eisner, 2005: 74). Tal vez así el artista-artesano podrá esgrimir su testimonio personal como un estatuto de primer orden para la Universidad y para atajar los constantes fenómenos de iconoclasia subliminal que asolan los pedestales del arte y la cultura de masas del siglo XXI. 


\section{Auriga o la Fragua de Hefesto: Génesis de un "Dibujo en el Espacio"}

Al tratar de explicar la tarea demiúrgica del escultor, Julio González reconocía en una entrevista que "solo una aguja de catedral puede indicarnos un punto del cielo en el que nuestra alma permanezca en suspenso" (González, citado en Carnduff Ritchie, 1956). Con esta imagen, el artista catalán revelaba su experiencia interior, añadiendo:

Como ocurre con las estrellas en la inquietud de la noche, que nos indican puntos de esperanza en el cielo, esta aguja inmóvil nos indica también un número sin fin. Son estos puntos en el infinito los precursores de un arte nuevo: dibujar en el espacio. El verdadero problema está [...] en el maridaje de la materia y el espacio, en la unión de formas reales con formas imaginarias, obtenidas o sugeridas por puntos concretos o por perforaciones; hasta confundirlas, siguiendo la ley natural del amor, haciéndolas inseparables, unas de otras, como sucede con el cuerpo y el espíritu (p. 42).

El impulso poiético es un fogonazo resbaladizo. Desata una lucha entre la imaginación y la materia, entre la memoria y el deseo... Dibujar en el espacio es moldear físicamente ese fogonazo juguetón que no espera y que, al pasar el tiempo, borra su propio rastro. Muchas veces, al reencontrarme con mi escultura Auriga (Fig. 1.), me doy cuenta de que no queda nada de aquel fogonazo primigenio que me impulsó a construirla. Ya no podría volver a hacerla como entonces. Al examinar sus formas herrumbrosas, sus discos de arcilla pintada y sus órganos descoloridos, me asalta la extrañeza. Recuerdo los días de su construcción como algo lejano, casi ajeno a mí mismo, como Dédalo al contemplar sus propias estatuas de cera, siempre dispuestas a alzar el vuelo según nos cuentan Platón —Menón, 97d; Eutifrón, 11c-dy Apolodoro - II: 63-. Aunque el creador, mítico o histórico, nunca logra desprenderse del todo de sus criaturas, se opera en ellas un cambio al encajar la última pieza, tras aplicar la pátina final (Frontisi-Ducroux, 1975: 95-118): es en ese momento postrero cuando la obra abandona su docilidad inicial para revestirse de un pálpito nuevo, ajeno a su hacedor. 

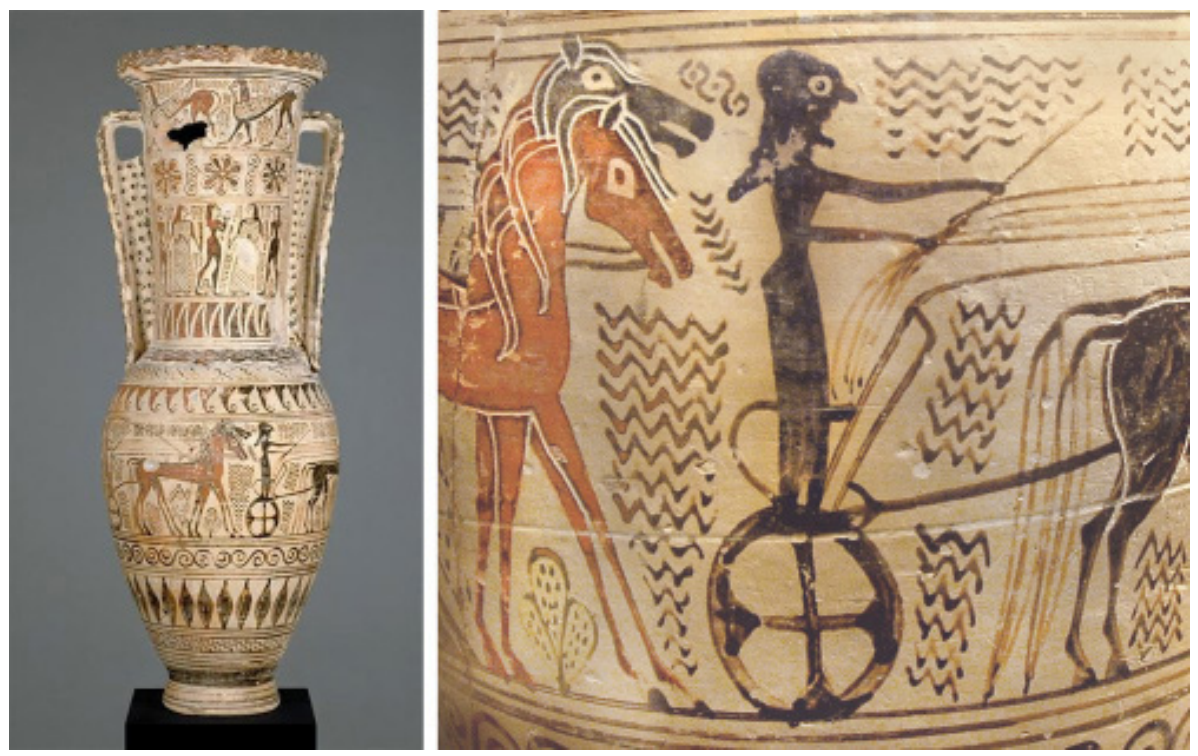

Figura 2. Loutrophoros proto-ático atribuido al Pintor de Analatos, c. 690 a.C. París, Musée du Louvre. (C) 2015 RMN-Grand Palais / Hervé Lewandowski.

He ahí otro tema de estudio que debería interesarnos: el pneuma vivificante, que entronca el soplo divino con la acción del artista, e incluso con la del niño y su juguete; un tema que se remonta a los relatos semíticos y las mitologías de los pueblos proto-orientales. Asimismo, es sabido que, desde la Grecia antigua, dar un nombre a la estatua equivale a despertarla, a dotarla de una identidad indeleble que la llama a la vida (Manson, 1982). Así ocurre también en la tradición cabalística del Golem (Scholem, 1978: 174-176. Idel, 2008) y en el cuento romántico de Pinocho, cuando el prudente Geppetto, antes de tallar el tronco mágico regalado por Maese Cereza, bautiza a su marioneta con el célebre apodo "ojos de pino" (Manson, 2003). En el caso que nos ocupa, "Auriga" fue desde el principio el nombre escogido para despertar a mi escultura, en alusión a los célebres conductores de bigas - carros de dos caballos (Fig. 2.). 

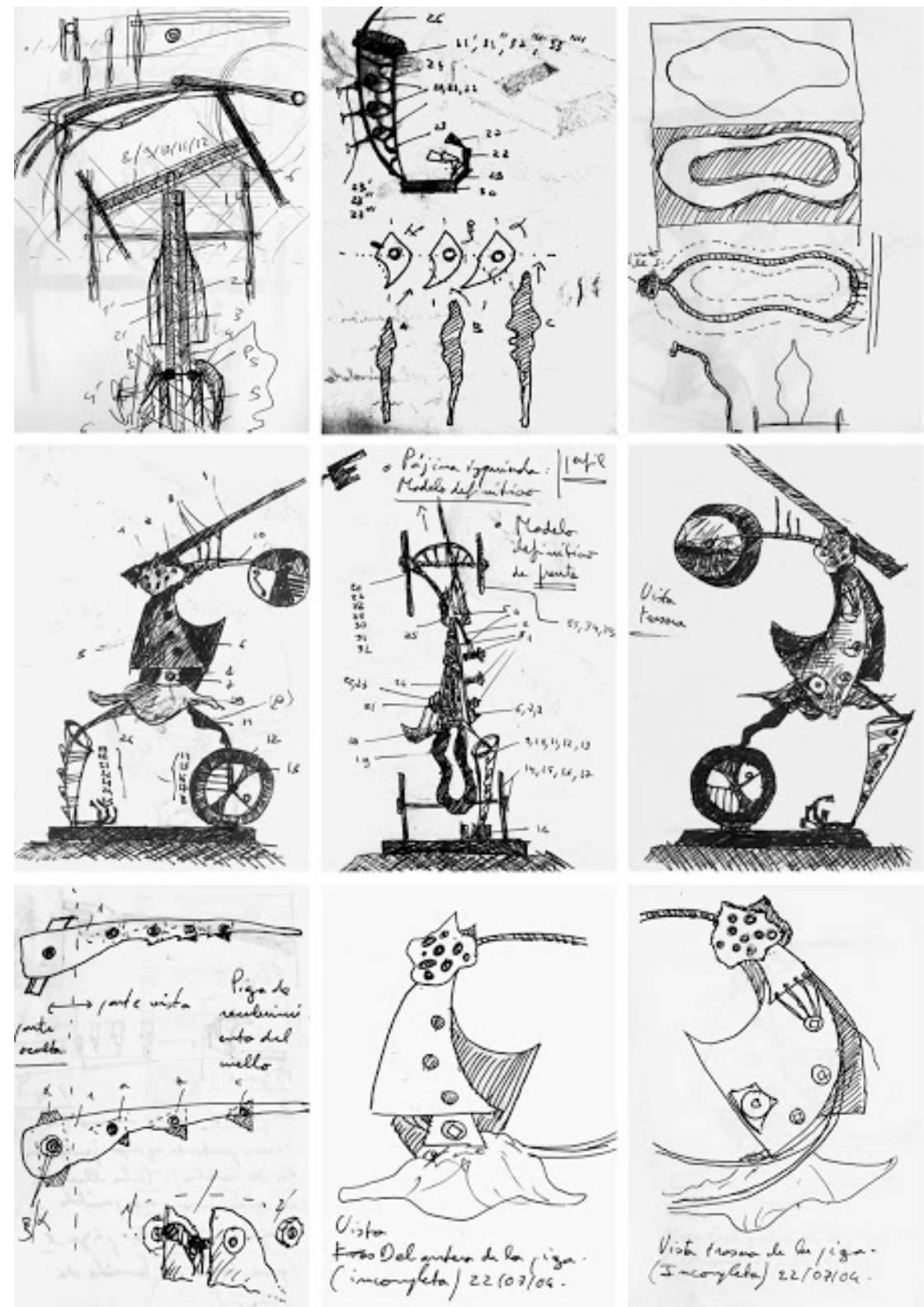

Figura 3. Oriol Vaz-Romero Trueba. Bocetos de Auriga, 2003-2004. Tinta s./papel, $12.3 \times 8.1 \mathrm{~cm}$. 
Cuando, a finales de 2003, Josep Llaberia Pascual, director general de Clínica Sagrada Familia de Barcelona, me encargó el proyecto de construir una escultura para la entrada del nuevo edificio de Consultorios, enseguida pensé en fabricar una criatura antropomórfica unida a las ruedas de un carro preindustrial, como las bigas olímpicas de Menelao y Orestes. Pero mi estatua encarnaría una carrera de mayor alcance: la de la vida humana. Apostado todavía hoy en el vestíbulo acristalado de la clínica, mi Auriga se alza como un maltrecho heraldo del valor cotidiano; como una señal para aquellos que, encorvados por el peso del sufrimiento físico o espiritual, se esfuerzan por participar día tras día en la gran carrera de la curación y la esperanza. Por este motivo, la escultura debía fabricarse con materiales capaces de reflejar tanto la fragilidad corporal como la fortaleza interior del hombre. El resultado, hoy a la vista de todos, fue una figura con un esqueleto de hierro negro y un rostro de cerámica de colores. Una cinta de hierro desgastada, encontrada en una vieja herrería asturiana, recuerda además la forma de un arco, mientras que el tronco del arquero presenta una coraza cortante que se tensa, presta para combatir la enfermedad.
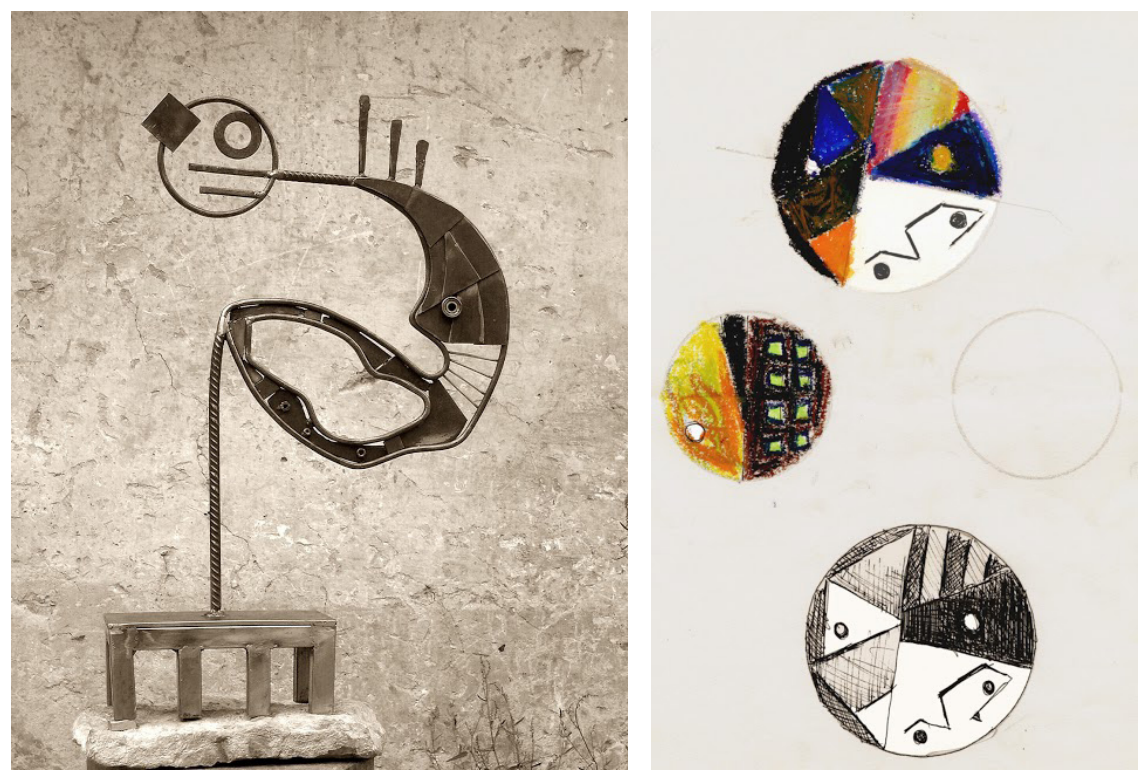

Figura 4. Oriol Vaz-Romero Trueba. Centinela del Bosque, 2002. Hierro/piedra fósil, $78,5 \times 51 \times 26,4 \mathrm{~cm}$.

Figura 5. Bocetos de rostros para Auriga, 2004. Técnica mixta s./papel, 29 x $17 \mathrm{~cm}$. 
Empecé a trabajar en los bocetos (Figs. 3, 5) a partir de mis antiguos personajes de fantasía y de algunos trabajos en hierro (Fig. 4.) que había emprendido entre 2001 y 2002 con mi maestro herrero y amigo Benjamín Martino Martino (1935-2010). Mientras la obra arquitectónica de Consultorios no era más que un amasijo de cables y hormigón, Auriga cobraba forma a base de pedazos fabricados en muy distintos lugares. Durante la primavera de 2004, comencé construyendo el tronco en la terraza de una conocida academia de arte, situada en la bulliciosa calle de Cucurulla. Pero la pieza más compleja nació durante el verano de ese mismo año en Soto de Sajambre, un pueblecito situado en el extremo noreste de la provincia de León, entre las frondosas estribaciones del Macizo Occidental de los Picos de Europa y el Desfiladero de Los Beyos. En este lugar fuera del tiempo, que tanto había marcado mi infancia, nació el brazo derecho de la figura, el arbotante de toda la estructura junto a las ruedas frontales. El aro de hierro, procedente de una rueda de carro del siglo XVII, las varillas y las demás piezas fueron dobladas y perfiladas sin recurrir al poder de la fragua.

De hecho, esta pieza tiene mucho que ver con el arte del yunque y el martillo. Esta habilidad inmemorial, creído tesoro del dios griego Hefesto, me fue inculcada por Benjamín Martino, enamorado desde niño de las montañas de Sajambre, pero también devoto estudioso y poeta andariego (Fig. 6a.). Él fue quien me enseñó también a domeñar el rigor con el arte de la soldadura. Los mitólogos sostienen que la fragua de Hefesto se encontraba en las fauces del Etna o acaso en la isla Eólea, bañada por las aguas del Tirreno. Aunque, si se me permite la digresión, los hechos demuestran que estuvo en el taller de Benjamín. Mis ayudantes no fueron ni cíclopes ni gigantes, sino la destreza de este hombre, cuyas manos de soldador se habían curtido en los altos hornos de la Alemania Occidental a principios de los '60. Este gran Sethas, "el que ablanda lo inflexible" (Reinhardt, 1961: 401-411), sometía las llamas y el metal a su voluntad, formando reja, portón o escudo con ímpetu relampagueante. De él aprendí a conciliar la paciencia del artesano con la intuición del artista, zanjando así — sin sospecharlo - la antigua pugna aristotélica entre el artista y el artesano, esa misma lucha que Filóstrato creyó haber resuelto al considerar que "la idea pinta y esculpe mejor que la maestría del artesano" (citado en Tatarkiewicz, 1958). 

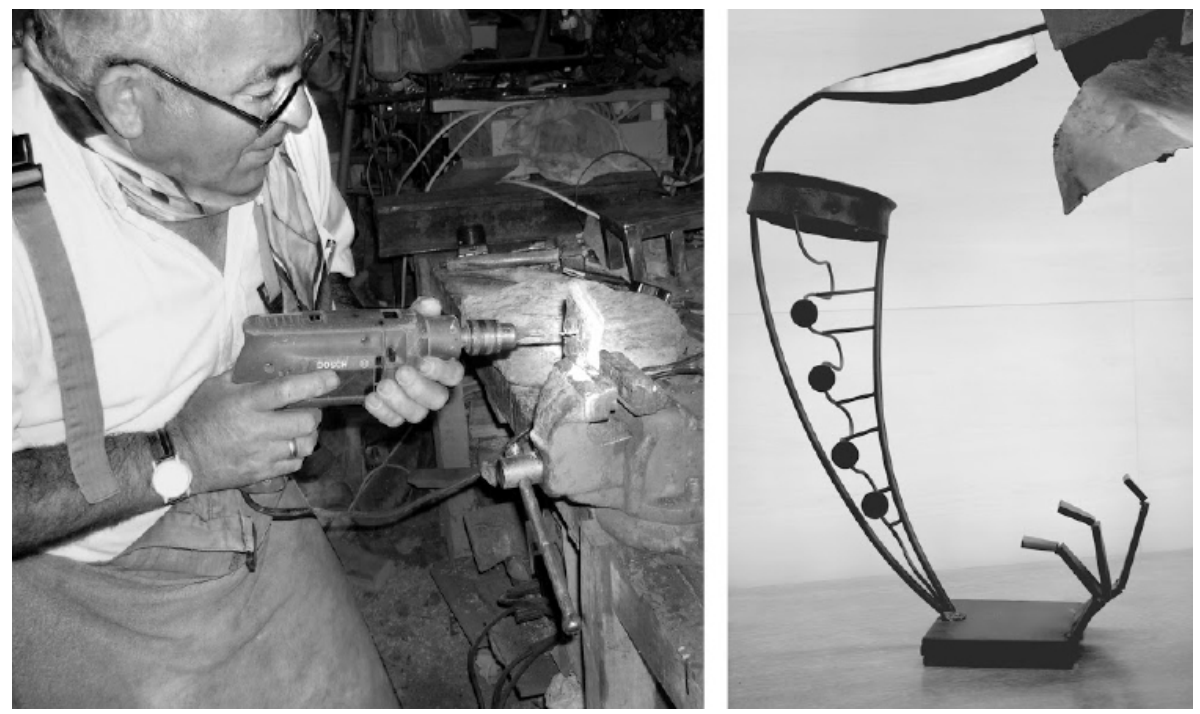

Figura 6. a) Benjamín Martino en su taller, Soto de Sajambre (León), 2004. b) Brazo derecho de Auriga.

Una vez acabado el brazo derecho (Fig. 6b.), debía ensamblar las demás extremidades al tronco y modelar la cabeza del automedonte. De regreso a Barcelona, la escultura había adquirido un tamaño desmedido, que acabó con la paciencia de los propietarios de la academia de arte. Trasladando la pieza de una punta a otra de la ciudad en ferrocarril, me permitieron trabajar en los sótanos de la Clínica Sagrada Familia. En esta etapa conté con el inestimable auxilio de los técnicos Joan Gual, Josep de Prádena y Agustín Arribas. El calor de las máquinas, las chispas del soldador y la oscuridad de la máscara protectora, acompasada por el chasquido del hierro fundente, me acompañaron durante semanas en un lugar bajo tierra, rodeado de enormes tuberías y de maquinarias malsonantes.

A pesar de ese inframundo asfixiante, apartado de toda luz diurna y en el que solía perder la noción del tiempo, logré dar forma al rostro de Auriga uniendo dos discos de terracota pintados con óleo (Fig. 7b). Esta solución se había presentado al jugar con el lápiz y las ceras de colores en mi cuaderno de bocetos. Sin embargo, el aspecto del cuerpo seguía siendo insulso y equívoco. Para acabar de ensamblar todas las piezas trasladé la escultura al todavía inacabado garaje del Edificio de Consultorios, pues hubiera sido imposible 
sacarla una vez montada por las calderas de la clínica antigua. Utilicé una pátina oscura para disimular la procedencia de las distintas piezas de hierro. La apliqué al armazón, al brazo de Benjamín — que había recorrido unos 870 kilómetros desde Soto de Sajambre — y a las ruedas de la biga, cortadas con chorro de plasma en la Facultad de Bellas Artes de la Universidad de Barcelona.

Sólo utilicé pigmentos en polvo, aglutinados con emulsión de cera de abejas, para las tres piezas superficiales del tronco, oxidadas artificialmente para permitir una mejor adherencia del pigmento. Rojo y amarillo de cadmio en la parte central y azul cobalto mezclado con manganeso y azul de Prusia para el regazo (Fig. 7a.). Estas piezas de color son los "órganos" internos de Auriga, puestos al descubierto como una herida sagrada. Evocan la fragilidad, la necesidad de curación, acentuada por el arqueamiento vertebral de toda la figura, tal vez como la herida mítica de Prometeo, encadenado por Hefesto en el monte Cáucaso según lo narran Esquilo y Hesíodo. Pero las llagas de Auriga no son la cruenta expiación de un castigo divino. Deberían entenderse, más bien, como un signo redentor, como una herida luminosa parecida a la del rey Amfortas, sanada finalmente por el poder divino conferido a Parsifal, ser “inocente convertido en sabio por la piedad", como sucede en la última de las óperas de Wagner (Jung \& Franz, 1988: 137-148 y 233-241).
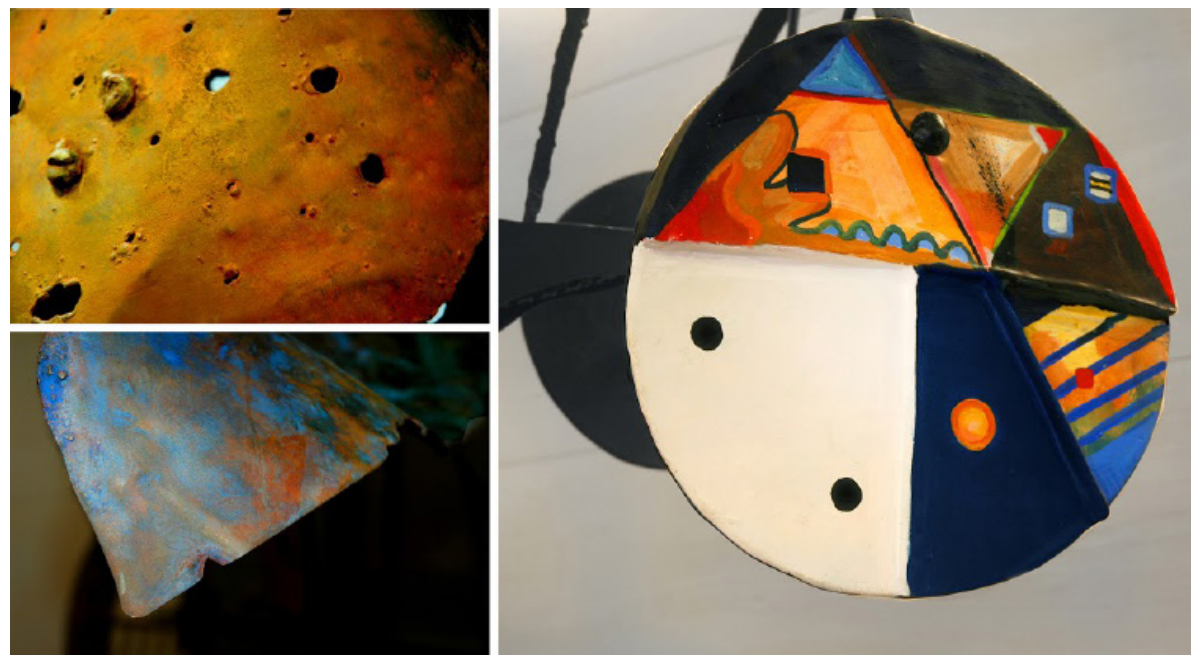

Figura 7. a) Órganos de hierro policromado. b) Rostro frontal de terracota. 
Por otro lado, la utilización de antiguos fragmentos de carros, de herraduras de caballo y el trabajo con varilla y planchas nos aproximan a la estética de Pablo Gargallo, pero también al Arsintes del escultor Ángel Ferrant, un juego de ensamblajes para niños que retomaremos más adelante (Arnaldo \& Bernardez, 1998). El antropomorfismo de estas esculturas y la utilización de planos superpuestos nos retrotraen, por un lado, a los personajes oníricos de mis pinturas de 1990, que representaban personajes de un bosque animado, como los que aparecen en los cuentos de hadas que mi madre me leía. Pero el retorno a la infancia no acaba ahí, pues durante el montaje de Auriga tuve la sensación de volver a tener en las manos mis antiguos juegos de Lego y Mecano, aunque esta vez, a mucha mayor escala gracias a los órganos robustecidos de la experiencia (Baudelaire, 2005: 357). Quizá por eso la escultura haya gustado tanto a los niños que durante todos estos años han cruzado el umbral del Edificio de Consultorios. Pues con Auriga, de un modo todavía imperceptible, había sentado las bases de mi próxima serie escultórica.

\section{Sibilas de Piedra: Entre Animismo Mágico y Juego Infantil}

Recuerdo un camino de tierra circundado por ondulantes viñedos. La exuberancia de estas colinas, apostadas entre Siena y Florencia, sosiega el espíritu al son de las estaciones, embellecidas por las virtudes de la vida geórgica. No en vano fue éste el antiguo hogar de los regios tarquinos y también de Cimabue, Giotto, Masaccio, Petrarca y Lorenzo el Magnífico. Mi serie de figuritas reunidas bajo el nombre de Sibilas nació también aquí, con el hallazgo inesperado de unos fragmentos de piedra muy especiales. En los ardientes caminos bordeados por cipreses centenarios dormían estos pedazos imperfectos y polvorientos, a la espera de ser reconstruidos. Por aquel entonces, en el verano de 2006, nada hacía sospechar que las sibilas de piedra se convertirían en prototipos de juguetes de madera y en el motor de mi tesis doctoral (Manson, 2014).

Al principio, esta serie de esculturas me enseñó lo sencillo que puede llegar a ser el ritual de la creación artística. Ante las emanaciones de nuestra "imaginación dinámica" (Bachelard, 1943: 15), se nos plantea además la pregunta acerca del significado mismo del acto creador como elemento determinante de la naturaleza humana. Pensando en estas cuestiones, cada día dedicaba una hora o dos a pasear por el camino de tierra florentina en busca de piedras para mis Sibilas. Los pocos aldeanos con los que me topaba en 
dirección a Montefiridolfi y San Casciano, no muy lejos de la tumba etrusca Dell'Arciere, me observaban como si estuvieran ante un chiflado o, cuanto menos, ante un niño-viejo que se entretiene jugando con cualquier cosa.
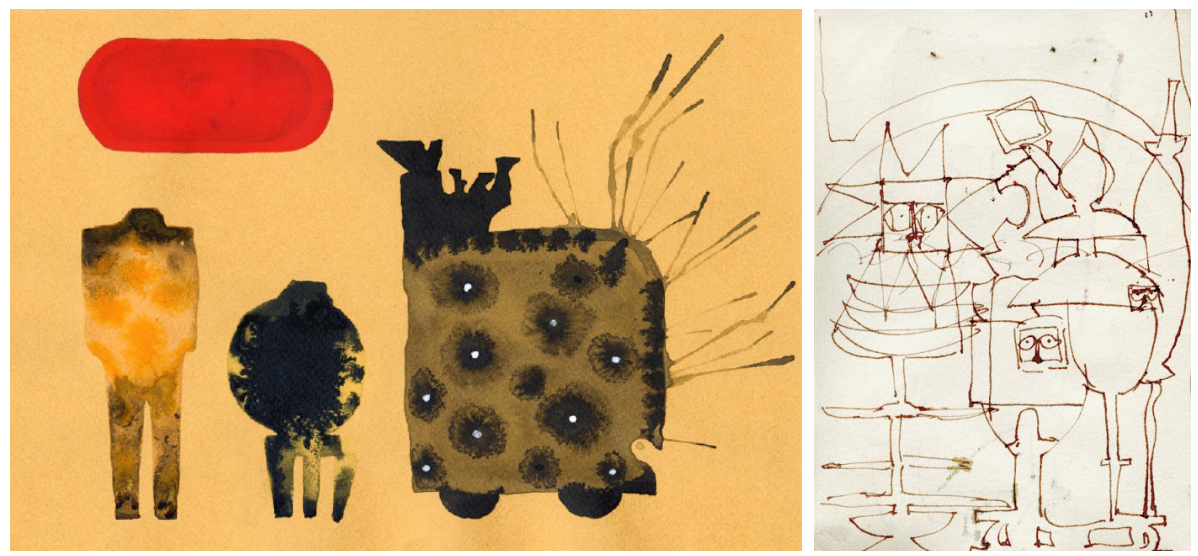

Figura 8. Oriol Vaz-Romero Trueba. Efigies trágicas VI (Hefesto, Pandora y el Carro de Helios), 2006. Técnica mixta s./papel, 29.7 x $21 \mathrm{~cm}$.

Figura 9. Boceto para Sibilas, 2007. Tinta s./papel, 14.8 x $10.2 \mathrm{~cm}$.

Para seleccionar las piedras más atractivas en medio de aquel piélago de formas minerales, me agachaba entre los huertos, colocándome muy cerca del suelo. El sombrero de paja me protegía del sol de mediodía. En ocasiones, la luz del crepúsculo, aliada con espejismos de sombras alargadas, también me permitía descubrir volúmenes que había pasado por alto a plena luz del día. Las piezas más adecuadas solían ser pequeñas. Una de las primeras fue un trozo de nácar del tamaño de un penique, marcada por el rastro de un gusano antediluviano que había agujereado la concha formando dos cráteres a modo de ojos. Para facilitar la tarea, ataba una bolsa de plástico a cada lado del cinto. En la de la derecha iba recogiendo los ejemplares más extraordinarios, que después utilizo para formar los rostros de mis personajes. Piedras irrepetibles como esas sólo se encuentran una o dos cada tarde, después de haber buscado mucho. Por el contrario, en la bolsa de la izquierda llevaba los pedernales más toscos, que sirven para construir extremidades, cuellos, cascos o torsos. 
Así lo anoté en mi cuaderno de viaje:

Un camino de lajas basálticas, enriquecido por cantos de extrañísimas formas y colores [...]. He encontrado cristales volcánicos hexagonales. También me he hecho con algunos fósiles de seres que no consigo descifrar. Delgados como largos tentáculos de hidras, fragmentos de rocas milenarias en tonos leonados. Hay gran cantidad de curiosas falanges sedimentarias. Las rocas revelan su secreto. Telarañas de relámpagos me han obligado a recluirme en mi habitación, que se ha convertido en un taller improvisado en medio de la campiña toscana. Me he puesto a jugar un poco, encajando unas piedras con otras; se me ha ocurrido una pequeña familia de figuras, caballos y guerreros, de mujeres lunares y troncos avizores... (Vaz-Romero, 2008: 57-62).

Fue precisamente el aspecto arcaico de estas formas naturales el que me impulsó a denominarlas "sibilas". No en vano es Heráclito, en un célebre fragmento recogido por Plutarco, el primero en dar testimonio de ese ser sobrenatural: "Sibila, con su boca delirante profiriendo palabras sin risas, sin adornos y sin perfumes, traspasa con su voz miles de años por virtud del dios" —Fr. 92 DK (Plut. De Pyth. Orac., 397a-b)—. Es como si en mis piedras del camino hubiese percibido la misma voz salvaje y primitiva que describe el filósofo de Éfeso, reclamando al caminante recogerlas para recomponer con ellas un cuerpo propio, dictado por el dios escondido.

En su poema Desechos de Neptuno, el pintor Gerard Sala describe el origen de los materiales que utiliza para sus cuadros y esculturas (2001: 33). Embargado por los recuerdos de su niñez en Mallorca, Sala pasea cada mañana por la orilla de la playa en busca de objetos que el mar ha rechazado. Ahora con barba y cabellos blancos, rememora así sus antiguos juegos de infancia, recolectando raíces, conchas o fragmentos de vidrio pulidos por el oleaje. Asimismo, Juan Eduardo Cirlot recuerda que

los mejores artistas contemporáneos han advertido de modo preciso y clarividente ese valor recóndito de los objetos humildes, sean naturales o artificiales; [...] Hans Arp, Max Ernst, Pablo Picasso, Joan Miró, Marcel Duchamp han recogido cosas en sus paseos por los arrabales de una ciudad o en la orilla del mar. Y los han recogido porque la voz peculiar de esos objetos sin valor y casi sin nombre se han insinuado de modo penetrante en su mente. La estética tradicional y académica, e incluso cualquier dictamen de belleza habrían sido desfavorables a esas 
recolecciones misteriosas, que los niños realizan constantemente en los paseos y en los parques, por enamoramiento de la pura objetividad. Hojas, piedras, trozos de hueso envejecido y amarillento, alambres retorcidos y oxidados, cristales de colores esmerilados por el roce constituyen los lugares comunes de esa arqueología intemporal (1990: 44).

La psicología moderna lo define como pareidolia, un fenómeno que consiste en percibir patrones figurativos en un conjunto de imágenes aleatorias (Lewis: 2013).

Desde que Auriga había sido oficialmente inaugurado en octubre de 2004, no había vuelto a "dibujar en el espacio". En ese lapso de tiempo, había llevado a cabo una serie de lienzos de gran formato titulada Efigies trágicas, gestada en los talleres de Pintura de la Facultad de Bellas Artes, donde Gerard Sala fue mi profesor, junto a Gloria Muñoz y Albert Gonzalo. Envueltas en un cromatismo vaporoso, rayano en los cuadros del primer Expresionismo americano, las siluetas de mis Efigies Trágicas fueron como el molde previo para la serie Sibilas. A principios de 2006, comencé a reducir el formato de los lienzos, despojando a las "efigies" de su dimensión mayestática original e incorporando ciertos rasgos anatómicos, primero a través de unos dibujos a tinta encargados por Albert Gonzalo (Fig. 8). En el verano de ese mismo año, ya en Toscana, las tintas acabaron cobrando mayor nitidez hasta el punto de hacerse tridimensionales con la serie Sibilas (Figs. 10-11). Pero eso sería simplificar el proceso en exceso.

En realidad, los juguetes de piedra surgen de algo mucho más imprevisto, esto es, de un animismo mitológico protagonizado por los cipreses y los paisajes que conocí recorriendo los viñedos toscanos de la familia Antinori. Por aquel entonces, me había sumergido en las obras de Novalis, Hölderlin y Philipp Otto Runge, cuyo animismo romántico conectaba con las fantasías de mi infancia en los bosques de Soto de Sajambre. Además, al ensamblar las piedras de aquel lugar, volví a experimentar la sensación de estar divirtiéndome con los juegos de construcción que tanto me habían maravillado de niño. Puede decirse, pues, que los paisajes etruscos me proporcionaron la experiencia de asombro que entrelazó definitivamente juego y animismo, recuerdos de infancia y arte. Tenía ante mí una estirpe de pequeñas sibilas rotas que reclamaban ser reparadas.

La materia natural se nos presenta en ocasiones como habitáculo milenario de un espíritu, de una presencia sobrenatural. La madera o la piedra pueden ser 
el hogar de un anima mundi inmanente, poderosa y escondida (Argullol, 2008: 36-43), que es música cinética del Universo si nos atenemos a las descripciones de los poetas latinos -Macrobio, Commentarii in Somnium Scipionis, 3: 11 12 - Un pensamiento que guarda relación, por ejemplo, con el modo en que Dios se revela a los hombres en el evangelio gnóstico de Tomás: "Partid un leño y ahí estoy. Levantad una piedra y allí me encontraréis" (Guillaumont \& Puech, 1959: 43). Siempre presente en diversas tradiciones europeas, este imaginario encaja con la idea inmanente de los ens spiritualis formulada por los filósofos neoplatónicos florentinos. Es Paracelso, sin embargo, quien lo expresará con más claridad en su Opus Paramirum de 1582: “por más que nuestros ojos vean físicamente, estamos ciegos en realidad ante la luz de la Naturaleza [...]. Bajo esta luz hay seres invisibles y que son tan admirables por cierto como lo visible" (1975: 7-12). Tanto es así que allí donde muchos sólo ven desechos y formas inservibles, el niño y el artista, "sin dejar de ver la forma exterior de dichos objetos, juegan y se divierten dialogando con ellos o, mejor dicho, con los entes que habitan en su interior", pues los convocan a la luz en el acto poiético. Por eso sus respectivos lugares de trabajo - la habitación del niño y el taller del artista - están "repletos de objetos extraños, fragmentos de la naturaleza o de artificios que no han sido recogidos por o para ser elementos decorativos, sino porque son los habitáculos de los entes mágicos de la creación" (Arola, 2007: 10-14).

Los viñedos de la familia Antinori resultaron ser la escenografía perfecta para una visitación inesperada del asombro. No sólo las piedras, sino los grandes cipreses adyacentes y las masas de bosque solitarias se me antojaban oscuros centinelas en los que parecía habitar una fuerza no muy distinta del anima mundi de los paganos (Fig. 9). Un animismo ancestral semejante relacionado con los árboles, aparece en la historia del joven Cipariso y su amarga transformación en ciprés tras el castigo de Apolo - Metamorfosis X: 106-147 - Por la misma razón, pero en sentido inverso, el gesto artístico que consiste en devolver la forma corporal a unas sibilas imaginarias se convierte en un acto mágico de liberación, en el cual lo invisible es "desocultado" y "traído adelante" (Heidegger, 2008: 25). He aquí lo que pude escribir durante el proceso de trabajo sobre este punto:

Creo que la mezcla de hierro y madera puede ennoblecer los misteriosos aerolitos descubiertos cerca de Montefiridiolfi. [...] Pongo las piedrecitas sobre la mesa y voy ordenándolas por tipologías formales. Regresar 
al camino se ha convertido en un peregrinaje cotidiano a la búsqueda de oráculos rotos. Mientras bordeo las bellas viñas de Santa Cristina, me pongo a discurrir estatuillas y pedestales de arcilla para formar un pequeño ejército de sibilas de juguete. [...] Ahora que llevo inscrita la Antigüedad en mi corazón, igalopad, deseos de infancia! ¡Galopad! Con ayuda de la Providencia encajo sus órganos, sus extremidades y recompongo sus rostros. [...] En los primeros instantes me siento como un niño solazándome con una arquitectura de piezas inagotables, pues la Naturaleza da en abundancia. A cambio, hay que tener paciencia y la imaginación de saber recolectarlas. [...] He comenzado a comprender qué desean las rocas de mí. Su voz es súplica de liberación. A las grandes montañas de Fantiscritti y Colonnatta deben de ser devueltos los mármoles de las primeras civilizaciones. Las columnas y las estatuas deben ser restituidas al torrente del Carrione. A Tasos y Proconeso sean repuestos el sarcófago de Nerón, la Tracia entera y las cariátides de Atenas y Macedonia. A cambio, los oráculos sibilinos devolverán a los artistas venideros los materiales necesarios para calmar su sed de creación. Pero no serán lujosos mármoles sino humildes piedras de los caminos. [...] El hombre se inclinará para cogerlas y poetizar con ellas; de un modo similar a como lo hacen los niños, cuando moldean modestas figuras de barro y juegan a construir universos enteros con lo que tienen al alcance de la mano. (2008: 167-197)

Ahora bien, ¿por qué llamarles juguetes, al fin y al cabo? Salta a la vista que estas esculturas no poseen una función lúdica preconcebida. De la misma manera que, debido a sus materiales y a su fragilidad, tampoco durarían mucho en manos de un niño. No es sino en el plano de lo metafórico que estas creaciones entroncan con el juego infantil. ¿Cuál sería, pues, la cualidad lúdica que emana de las sibilas de piedra? Para responder debemos acudir a la antropología y a la psicología evolutiva y analizar así dos mecanismos. El primero reside en la manera de imaginar cada escultura, pues interviene, como hemos visto, un mecanismo animista presente en el niño y en muchas culturas antiguas — pareidolia - . El segundo recae en el modo de conformar la "anatomía" de dichas figuras, donde se produce un acercamiento a los juegos de construcción de mi infancia. 

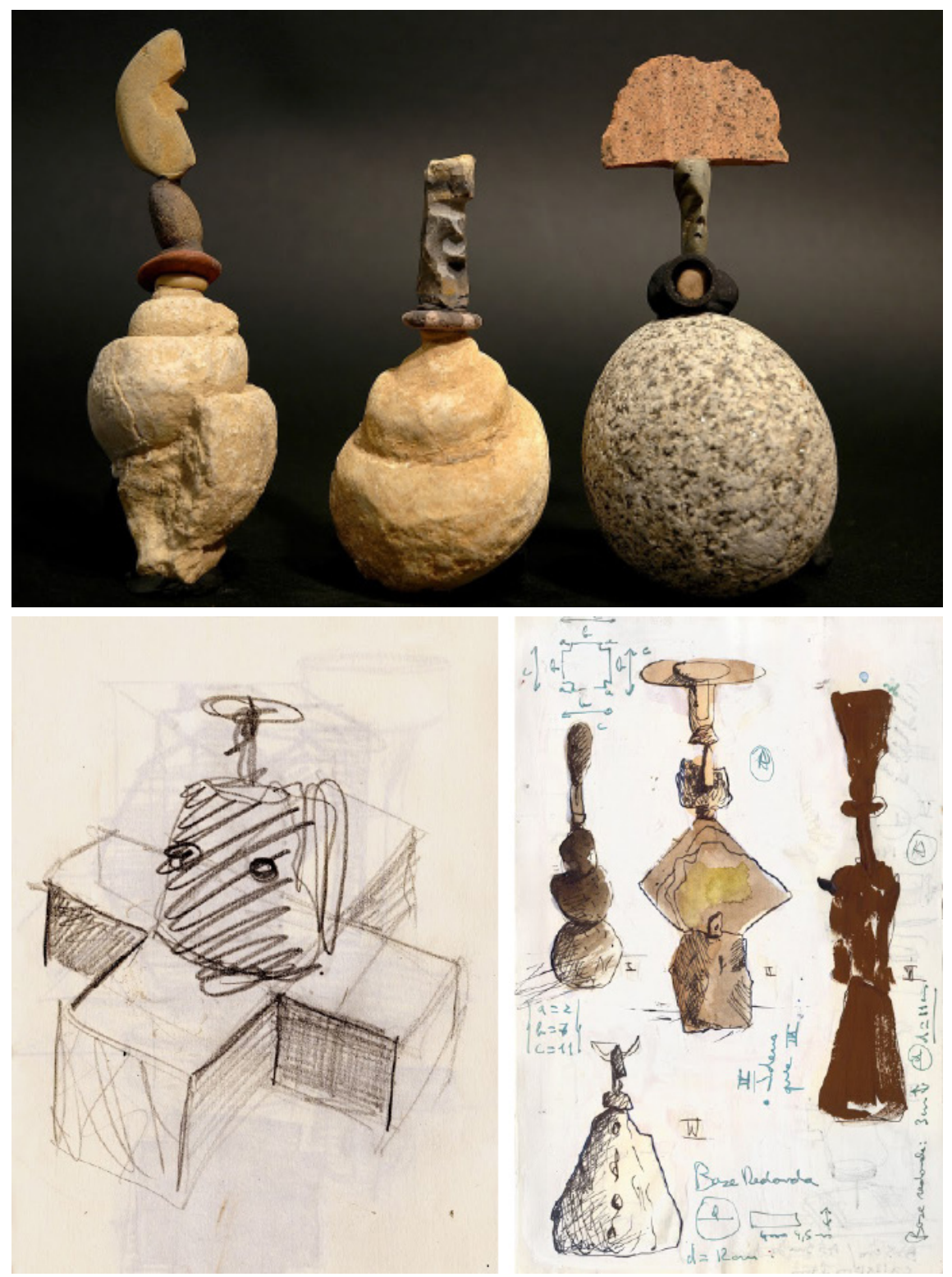

Figura 10. Oriol Vaz-Romero Trueba. Sibilas o "juguetes de piedra", primera serie (2006-2007).

Figura 11. a-b) Bocetos de pedestales y Sibilas, Cuaderno italiano (2007). 
Aunque el niño y el hombre primitivo parten de niveles de experiencia distintos, se enfrentan a fenómenos ambientales que no saben explicar del todo. En ellos, la confrontación con lo desconocido puede tornarse causa tanto de fascinación como de horror (Zambrano, 1955: 174-175). Según afirmaba el antropólogo Edward B. Tylor a propósito de la fantasías de la mente, existen vasos comunicantes entre los juegos infantiles y los ritos de los adultos (1871: 65-66), pues ambos comparten una forma básica de animismo como estrategia para iniciarse en el mundo (1866: 72). Aunque la fantasía del niño poco tiene que ver, en sus motivos, con la compleja mitopoiésis de los pueblos ancestrales, el epistemólogo Jean Piaget admite que en la infancia biológica y en la infancia de las culturas prevalece el hecho de "prestar conciencia a los objetos" (2001: 169). Por otra parte, el pedagogo suizo Édouard Claparède matiza el paralelismo señalando que "el niño deforma la verdad [...] pero no tiene intención de engañar, sino que prolonga una comedia de la cual él mismo es juego a medias" (1916: 448). Por tanto, el niño no deja de ser prisionero de sus fabulaciones, mientras que el adulto es capaz de manejar a voluntad sus fantasías. Por eso, el animismo cultural — adulto- actúa como un instrumento facultativo, como un crisol de imágenes cuyo cometido no es el de deponer la realidad, el de escapar del mundo real como hace el niño, sino de forjar un lenguaje simbólico con el que revelar las realidades trascendentes. De hecho, el animismo lúdico infantil es fruto de una imaginación mucho más reducida, ya que se asienta sobre el desconocimiento de los principios básicos de causalidad.

Bien es verdad que el mundo mágico del niño, al igual que el del hombre primitivo, rebosa de fuerzas extrañas, basadas en las leyes de la coincidencia y la similitud. Dichas fuerzas sobrecogen los sentidos, inducidas por una forma primaria de asombro. Como ya expusimos anteriormente (Vaz-Romero, 2010), el asombro es una convulsión de la imaginación que no puede contenerse a sí misma. Por eso el desbordamiento del asombro puede desembocar en poíesis: en forma de juego en el niño, de obra poética en el artista y de mito o liturgia en los diversos estratos de la cultura mitopoyética (Huizinga, 1980: 14). Con razón sostiene el filósofo Pierre Jean-Jouve que el niño, el artista y el místico actúan arrebatados por la maravilla del mundo:

el poeta posee una constante: la emoción positiva del asombro. [...] Sin embargo, la admiración no es sólo un don del poeta, es la ciencia del niño. [...] Los santos y los grandes artistas han vivido en el asombro. [...] El arte, al tiempo que sirve para eternizar una imagen, tiene como 
primer designio el de resucitar en nosotros los estados de infancia, es decir, de asombrarnos. El asombro es la capacidad de transferir un aura de gozo respecto de ese objeto imprevisible cuya presencia nos hechiza y nos colma.

Ahora bien,

el niño, conducido por su narcisismo, se asombra por todas las cosas; pero el adulto debe obligarse a poner en marcha ese mecanismo. Al lograrlo, aunque con mayor dificultad, dado que la dimensión de la vida ordinaria se le opone constantemente, obtiene a cambio un asombro mucho más secreto, más solemne y significativo (1954: 166-168).

De un modo similar, las tesis de la Escuela de Ginebra sostienen que el desencadenante del juego infantil, del impulso artístico y de los mitos se fundamenta en el acto de sorprendente asimilación del objeto hallado con el ente imaginado. Por consiguiente, cualquier cuerpo natural, incluso sin una forma concreta aparente, puede llegar a desencadenar una imagen imitativa, una imagen po(i)ética.

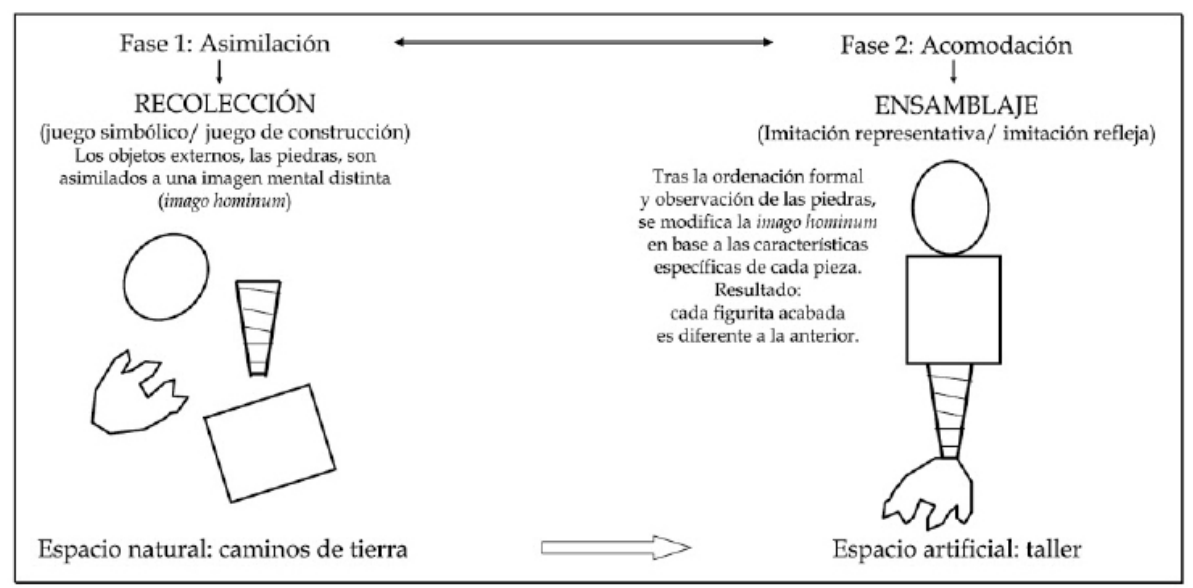

Figura 12. Análisis del proceso creativo de la serie Sibilas. 
Así lo confirma Piaget al observar que "en el juego con juguetes, el papel del símbolo es asimilación que prima sobre la acomodación" (2001: 295). La imagen mental no necesita adecuarse demasiado a las variables físicas del objeto para operar su efecto simbólico. El niño, como el artista, no tiene necesidad de modificar por completo su entorno para representar lo que imagina; asimilará sin problemas su idea de "caballo" a una piedra, a un hueso, a una rama siempre y cuando el objeto asimilado posea unas características mínimas que aseguren aquella función mental. En sus Meditations on a Hobby Horse or the Roots of Artistic Form, Gombrich coincide en afirmar que "el 'primer' caballo de madera $[\ldots]$ no era probablemente una imagen en absoluto: sólo un palo que se consideraba como caballo porque uno podía cabalgar en él. El tertium comparationis, el factor común, era la función más que la forma. $\mathrm{O}$, más exactamente, el aspecto formal que cumplía los requerimientos mínimos para realizar la función; pues cualquier objeto cabalgable podía servir de caballo [...]. La representación no depende de semejanzas formales, más allá de los requerimientos mínimos impuestos por la función. Son llaves que, como por azar, encajan en cerraduras biológicas o psicológicas" (1991: 45-46).

El ejemplo de Gombrich refulge en un testimonio tan antiguo como los versos de Horacio: "aedificare casas, plostello adiungere muris [...] equitare in harundine longa" — Sátiras II: 3, 246-248-. El poeta romano alaba la naturalidad con la que el niño es capaz de "construir casitas de juguete, uncir ratones a un carrito y cabalgar sobre una larga caña de rosal". Pero también Leonardo, en su célebre Trattato della Pittura, apela varias veces a este mecanismo pueril para enardecer el ingenio del artista:

cuando veas alguna pared manchada en muchas partes, o algunas piedras jaspeadas, podrás mirándolas con cuidado y atención advertir la invención y semejanza de algunos países, batallas, actitudes pronas de figuras, fisionomías extrañas, ropas particulares y otras infinitas cosas; porque de semejantes confusiones es de donde el ingenio saca nuevas invenciones" (1999: 8-9).

Como un magnífico corcel cobra forma de pronto en una simple vara de árbol y como un rostro monstruoso surge en la mancha de humedad de un muro viejo, también el cuerpo de mis sibilas se hace imagen en las piedras del camino (Fig. 12).

Tras la fase animista-asimilativa (Fig. 12-Fase 1), el proceso escultórico prosigue en el taller mediante un segundo mecanismo psicológico, 
300 Oriol Vaz - Auriga y mis juguetes de piedra
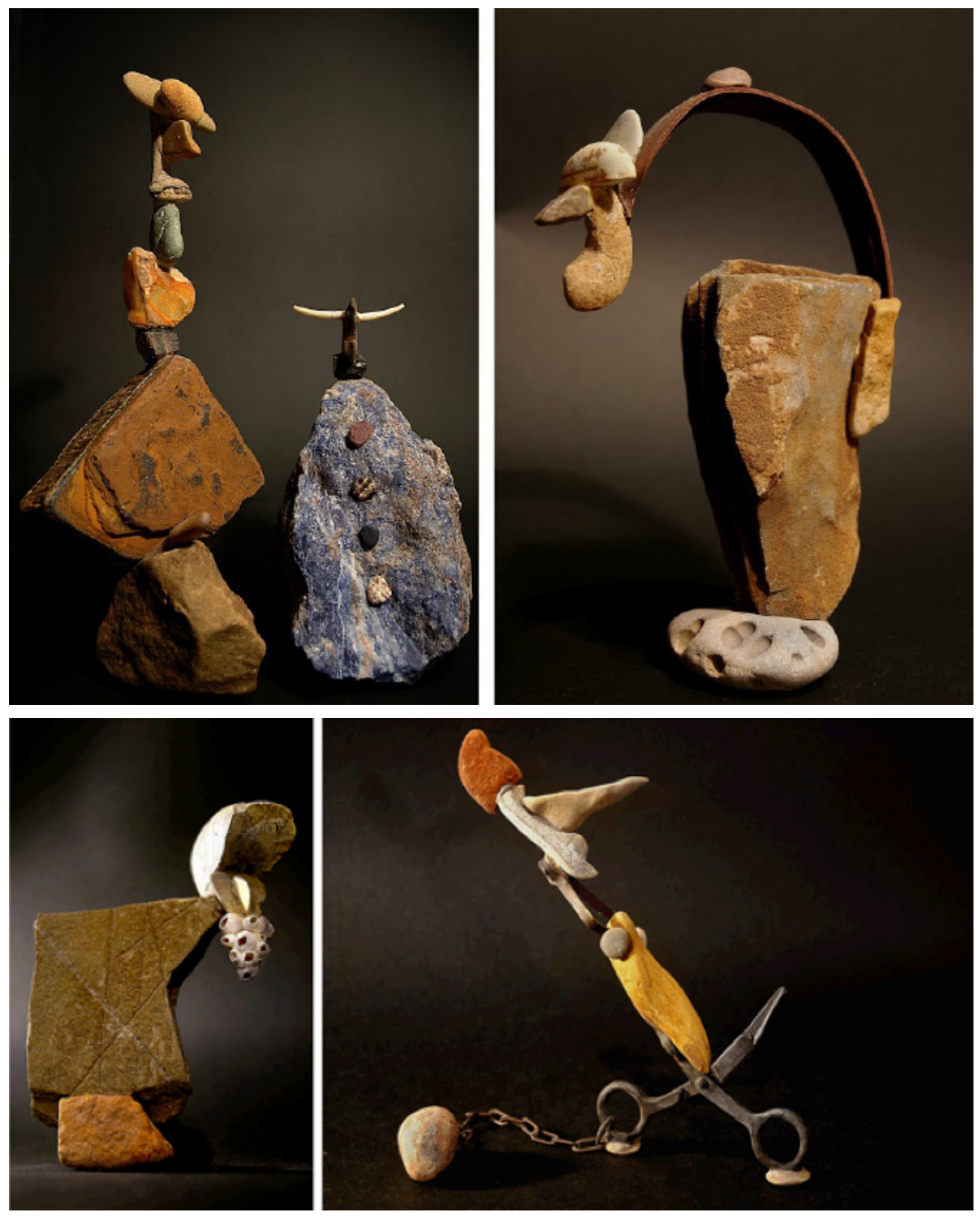

Figuras 13-14. Oriol Vaz-Romero Trueba. Sibilas o "juguetes de piedra", serie de 2007 a 2009. 
igualmente característico de la mente infantil: la acomodación. Para conferir una forma tangible a su escultura, como le ocurre al niño que fabrica sus propios juguetes, el artista "requiere de imágenes mentales previas, lo cual supone un grado de reproducción, o sea, de acomodación" (Piaget, 2001: 295). El muchacho evocado por Horacio o el artista-artesano referido por Gombrich han asimilado una rama del bosque a un caballo imaginario. Pero, en ocasiones, la afordancia ${ }^{2}$ natural del objet trouvé no siempre basta. Es entonces cuando el creador decide "acomodar" el material encontrado a la imagen mental deseada, eliminando para ello sus impurezas, rebajando sus formas más toscas, rectificando su curvatura o pintándolo con vivos colores. Lo mismo ocurre en $\mathrm{mi}$ taller, tras jugar a las combinaciones, cuando me pongo a ensamblar las diferentes piedras entre sí (Fig. 12-Fase 2). Aunque he tratado de dejar cada pieza intacta, a menudo me veo en la obligación de lijar los cantos, de agujerear ciertas piedras o de pintarlas para disimular los puntos críticos de unión. De este modo, trato de acomodar los materiales recolectados a la anatomía de la sibila que se va perfilando en mi mente y en el cuaderno de bocetos. En definitiva, el resultado depende de un delicado equilibrio entre asimilación y acomodación.

Finalmente, en ese juego de equilibrios, resulta fundamental saber construir una figura de aspecto ambiguo. En otras palabras, obtener una escultura de iconicidad mínima o "restringida", por utilizar la expresión de John White (2007). Lo suficientemente sugerente como para captar la atención del espectador y lo bastante imprecisa como para dejar que sea él quien "acabe" la figura en su mente. Recuerdo una experiencia parecida al contemplar los Prigioni o Schiavi de Miguel Angel en la Accademia de Florencia. A primera vista, se palpa una tensión dolorosa en esos cuerpos musculosos capturados en el bloque de mármol (Gilbert, 2003). El Atlante y el Esclavo que se despierta impresionan por el esfuerzo desesperado del hombre por redimirse del peso inmundo que le ahoga. Nunca conoceremos su auténtico rostro, pues queda fundido con la roca. De ahí que el espectador sienta la necesidad de "liberarlo" o, mejor dicho, de terminar la labor que el artista no pudo o no quiso completar.

Como el "non finito" impuesto por Miguel Angel a sus prisioneros de mármol, mis ens spiritualis también permanecen capturados en sus armaduras de piedra toscana. Por eso la ausencia en sus semblantes de una expresión facial definida. Tampoco tienen brazos ni piernas (Figs. 13-14). Pero estas ausencias no impiden sugerir el aspecto de un cuerpo vivo. Pedazo a pedazo, todas las figuras parecen incompletas. Sugieren en vez de representar. Sus volúmenes reclaman el juego último de nuestra imaginación. Mientras que Buonarroti trabajaba desgastando el bloque de piedra hasta hallar en él la forma del ente 
imaginado, mi trabajo consiste en recolectar y ensamblar, como ocurre con las Esculturas intactas de Ángel Ferrant, las cuales nos incitan a concluir la pieza con las imágenes "vivas" de nuestra mente (Maderuelo, 158-161). No en vano esta serie de esculturas de piedra brindaron al artista madrileño la idea de fabricar el Arsintés (Fig. 15), un juego combinatorio infantil basado en plantillas geométricas para construir cualquier figura, conformada según la imaginación del jugador que las manipule (Ortega Cubero: 2010).
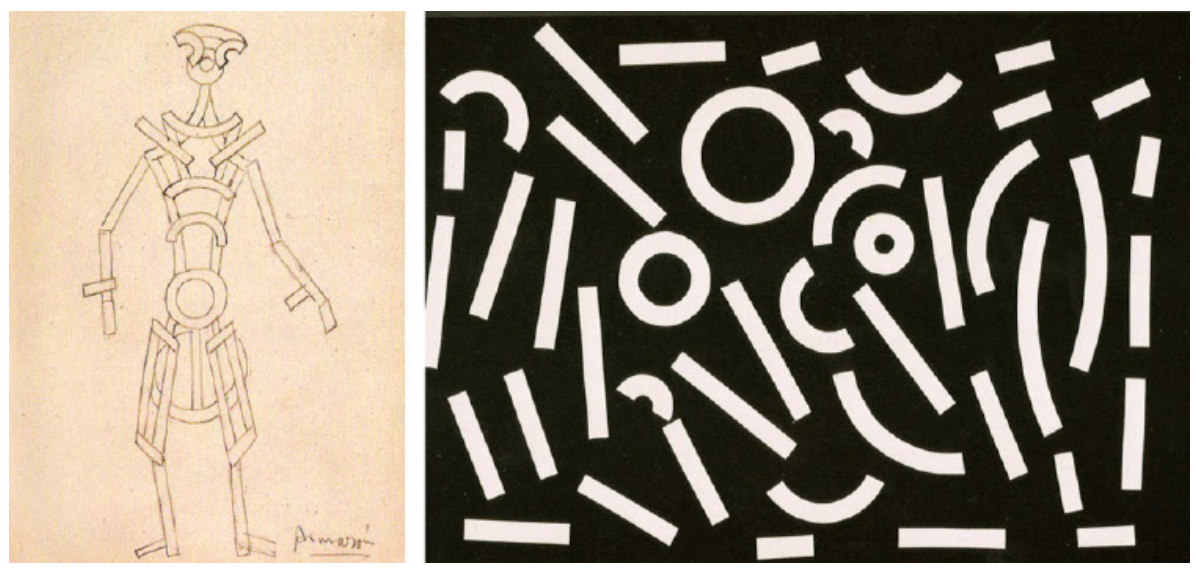

Figura 15. Ángel Ferrant, 1935-1940. a) Dibujo que representa un personaje creado con las piezas de Armazón. b) Juego de plantillas Armazón-Arsintes. Archivo Ángel Ferrant, C.A.C. (C) Valladolid, Museo Patio Herreriano.

Hace más de una década que mis tránsitos por los antiguos caminos de Etruria me han llevado a recoger materiales heteróclitos que compartían, sin embargo, un mismo destino: haber sido olvidados por la mano del Hombre. Recolectando fragmentos de madera, cencerros y otras piezas de hierro, cuero, nácares y toda clase de piedrecillas he ido formando un elenco de runas escultóricas con el que construir figuras antropomórficas y vehículos de los antiguos pueblos del Mediterráneo y Mesopotamia, recordando acaso todos aquellos artefactos que había visto en los libros de arqueología que mi padre me enseñaba cuando era niño. Entonces, comprendiendo la relación que existe entre el impulso del artista, del niño y del místico, consideré una nueva vía de trabajo: el juguete de artista. Este afán sigue vigente en mi obra, 
incluso más allá de la serie Sibilas, como así lo atestiguan los juguetes de madera que espero seguir construyendo (Fig. 16). Estas figuras talladas en madera de pino son livianas, compactas y resistentes. Poseen articulaciones y son desmontables. Cualidades propias de los juguetes tradicionales y que quizá permitan que un día puedan convertirse en "recipientes de asombro" de otros niños.

Pero esta última serie, aún inconclusa, no sólo podría acercarnos a las tradiciones animistas paganas y a la psicología de los juegos infantiles, sino que alcanza la vasta tradición de la artesanía juguetera preindustrial e incluso el misterio redentor del madero del Gólgota. Pero esta es ya otra historia y deberá ser contada en una ocasión más propicia. En última instancia, el recorrido personal y cronológico que he presentado no es más que una tentativa de razonar un impulso creador demasiado complejo como para que podamos llegar a comprenderlo en su totalidad. Como todos los misterios, nos brinda, eso sí, una intuición: que el juguete es algo profundamente serio y que, como aseguraba José Corredor Matheos, "el juego tiene el valor simbólico de creación mundo" (1999), entrelazando así al niño con el artista y el místico. Sin duda, un vínculo que no debería dejar indiferente a los estudiosos de las Humanidades. A fin de cuentas, un conocimiento formado sin palabras en el taller de artista nos ha conducido hasta territorios académicos por conquistar. Por lo cual deseo que los artistas que hoy realizan sus creaciones en ámbitos universitarios se atrevan a tirar del hilo de sus creaciones para descubrir que, tras él, viene la totalidad del ser humano, desde la remota Antigüedad hasta nuestros días. 
304 Oriol Vaz-Auriga y mis juguetes de piedra

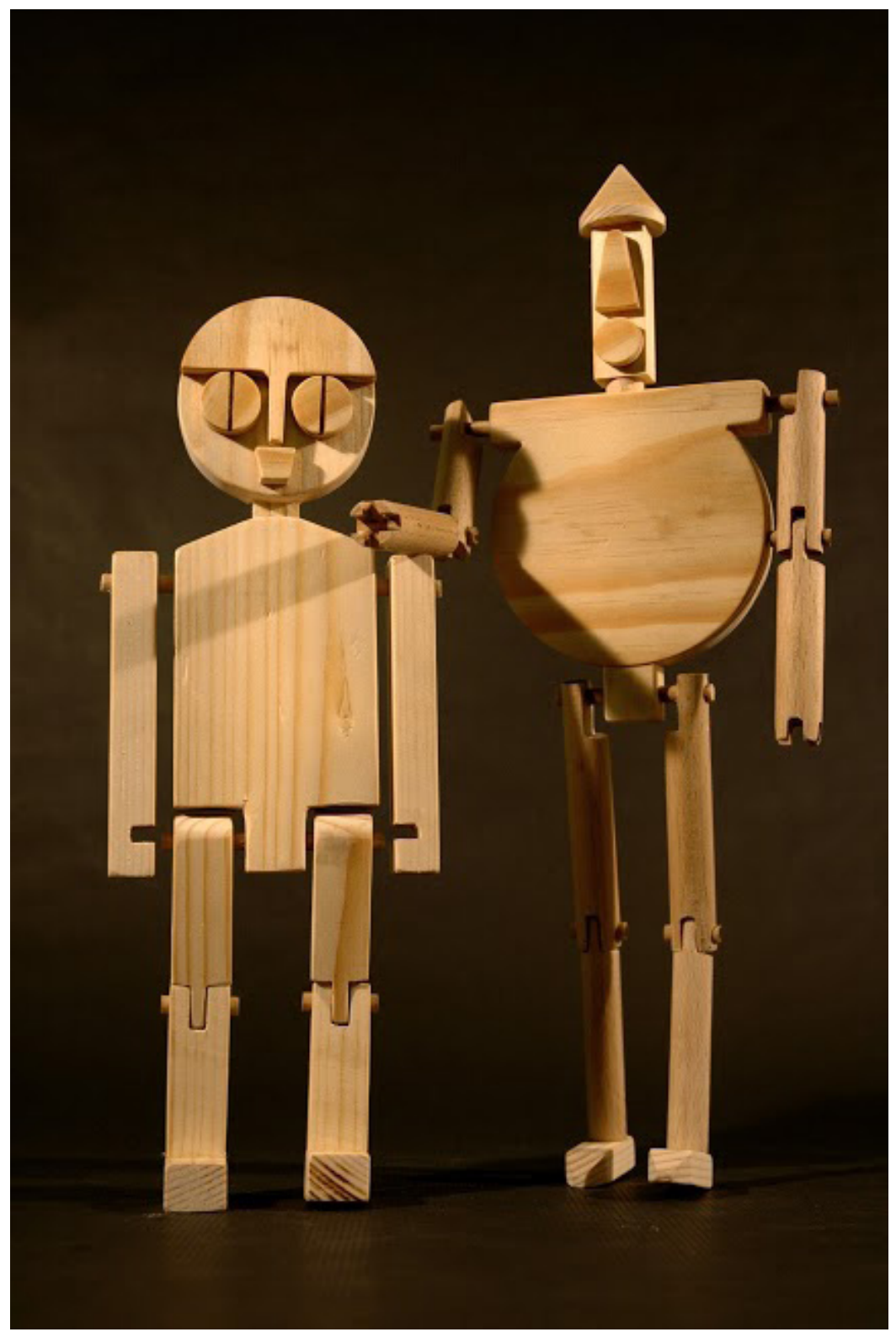

Figura 16. Oriol Vaz-Romero Trueba. Juguetes articulados, madera de pino. Prototipos de 2010. 


\section{Notas}

${ }^{1}$ Conferencia pronunciada por Eduardo Chillida en la I Semana de la Escultura, enero de 1981, Facultad de Bellas Artes de la Universidad de Barcelona.

2 Afordancia: neologismo creado por Kurt Lewin, formado a partir del verbo "to afford" (proporcionar, ofrecer la posibilidad), que se refiere a las posibilidades de interacción entre el ser y su entorno. Por ejemplo, una silla ofrece entre otras la afordancia de sentarse en ella a un ser humando y de caminar sobre ella a una rata. R. Arnheim (1987). Art among the Objects. Critical Inquiry, 13 (4), 677-685. Cf. A. Scarantino (2003), Affordances Explained. Philosophy of Science, 70 (5), 949-961.

\section{Referencias}

Argullol, R. (2008). El Héroe y el Único. Barcelona: Acantilado.

Arnaldo, J. \& Bernárdez, C. (1998). Saber empezar sin saber. El Arsintes de Ángel Ferrant. In C. Pérez (Cat.), Infancia y Arte Moderno (pp. 60-71).

Valencia: IVAM.

Arola, R. (2007). La Visión interior. In A. Arola (Ed.), Diez años luz (p. 1014). Barcelona, Santa \& Cole.

Bachelard, G. (1943). L'Air et les songes: essai sur l'imagination du mouvement. París: José Corti.

Baudelaire, Ch. (1980). Euvres complètes. Paris: Robert Laffont.

Baudelaire, Ch. (2005). Salones y otros escritos sobre arte. Madrid: La Balsa de la Medusa.

Corredor Matheos, José (1999). El juguete en España. Madrid: Espasa Calpe.

Cirlot, J. E. (1990). El mundo del objeto a la luz del surrealismo. Barcelona: Anthropos.

Carnduff Ritchie, A. (1956). Julio González. Nueva York: Museum of Moden Art.

Claparède, E. (1916). Psicología del niño y pedagogía experimental.

Madrid: F. Beltrán.

Dilthey, W. (1990). Gesammelte Schriften: Die geistige Welt (5). Gotinga:

Vandenhoeck und Ruprecht.

Dilthey, W. (1944). El mundo histórico. México: Fondo de Cultura

Económica.

Eisner, E. W. (1979). The enlightened eye: qualitative inquiry and the

enhacement of educational practice. Nueva York \& Toronto: Macmillan.

Eisner, E. W. (2005). On the differences between scientific and artistic 
approaches to qualitative research. Reimagining Schools (pp. 68-75).

Nueva York: Routledge.

Friedländer, M. J. (1969). El Arte y sus secretos. Barcelona: Juventud.

Frontisi-Ducroux, F. (1975). Dédale. Mythologie de l'artisan en Grèce ancienne. París: Maspero.

Gilbert, C. E. (2003), What is expressed in Michelangelo's "Non-Finito". Artibus et Historiae, 24 (48), 57-64.

Gombrich, E. H. (1979). Arte e ilusión. Barcelona: Gustavo Gili.

Gombrich, E. H. (1991). Meditations on a Hobby Horse or the Roots of Artistic Form (1951). In S. Everett (Ed.), Art Theory and Criticism (pp. 41-54). Jefferson, NC: McFarland.

Guillaumont, A. \& Puech, H.-C. (1959). L'Évangile selon Thomas. Leiden: E. J. Brill.

Heidegger, M. (2008). Caminos de Bosque. Madrid: Alianza.

Huizinga, J. (1980), Homo ludens. A study of the play-element in culture.

London: Routledge \& Kegan Paul.

Idel, M. (2008). El Golem. Tradiciones mágicas y místicas del judaísmo

sobre la creación de un hombre artificial. Madrid: Siruela.

Jouve, P.-J. (1954). En Miroir. Journal sans date. París: Mercure de France. Jung, E. \& Franz, M.-L. (1988). La Légende du Graal. París: Albin Michel. Leonardo (1999), Tratado de la Pintura (Codex Vaticano Urbinate, 1270).

Barcelona: Alta Fulla.

Lewis, D. (2013), The Power of the Visual. In Impulse (p. 72-87).

Cambridge, MA: Harvard University Press.

Maderuelo J. (2012), Caminos de la escultura contemporánea. Salamanca:

Ediciones Universidad de Salamanca.

Manson, M. (1982). Le mythe de Pygmalion est-il un mythe de la Poupée?.

In R. Chevalier (Ed.), Colloque Présence d'Ovide (p. 101-137). París:

Belles Lettres.

Manson, M. (2003). Pinocchio, Pygmalion et la Poupée. In J. Perrot (Ed.),

Pinocchio. Entre texte et image (pp. 101-114). Bruselas: Peter Lang.

Manson, M. (2014). Recensión de la tesis de Oriol Vaz-Romero Trueba,

El Artista y el Juguete. Viajes al Imaginario Occidental, desde la

Antigüedad al Romanticismo. Barcelona, Research, Art, Creation, 2 (1),

126-135. Doi: 10.4471/brac.2014.05. URL: http://dx.doi.org/10.4471/

brac. 2014.05

Ortega Cubero, I. (2010). Los secretos del Arsintés bajo el prisma de la teoría emergente de los datos. Arte, Individuo y Sociedad, 22 (2), 103- 
121.

Panofsky, E. (1955). Meaning of the Visual Arts: Papers in and on Art

History. Garden City, NY: Doubleday Anchor Books.

Paracelso (1975). Liber paramirum ... Ed. de G. de Givry. Milán: Archè.

Piaget, J. (2001). La representación del mundo en el niño. Madrid: Morata.

Quílez Bach, M. (1990). La enseñanza del arte y la Universidad. Arte,

Individuo y Sociedad, 3, 185-189.

Redlich, F. (1975). Autobiographies as Sources for Social History:

A Research Program. Vierteljahrschrift für Sozial und

Wirtschaftsgeschichte, 62 (3), 380-390.

Reinhardt, K. (1961). Die Ilias und ihr Dichter, Gotinga, Vandenhoeck und Ruprecht.

Rodríguez-Cascante, F. (2000). El género autobiográfico y la construcción del sujeto autorreferencial. Filología y Lingüistica, 26 (2), 9-24.

Sala, G. (2001). Amb la veu als ulls. Barcelona: Viena.

Schiller, F. (2005). Kallias. Cartas sobre la educación estética del hombre.

Barcelona: Anthropos.

Scholem, G. (1978). La Cábala y su simbolismo. Madrid: Siglo XXI.

Tatarkiewicz, W. (1958). Grecy o sztukach naśladowczych. Sztuka i krytyka, 9 (33-34), 113-121.

Tylor, E. B. (1866). The Religion of Savages. The Fortnighly Review, 30, 71-72.

Tylor, E. B. (1871). Primitive culture. Researches into the development of mythology, philosohy, religión, art, and custom... (t. 1). Londres: J. Murray.

Vaz-Romero Trueba, O. (2008). Epifanía de la Frontera. Génesis de las Sibilas y otros escritos desde Italia. Barcelona: F. Diagonal [autoedición].

Vaz-Romero Trueba, O. (2010). El poder creador del asombro. In O. VazRomero T. (ed.), Caminos del Pintor. De los lenguajes del arte al proceso creativo (pp. 101-254). Barcelona: Centro de Estudios de la Escultura Pública y Ambiental.

White, J. J. (2007), Forms of restricted iconocity in modern avant-garde poetry. In E. Tabakowska, C. Ljungberg, O. Fischer (Eds.), Insistent Images (pp. 129-154). Ámsterdam: J. Benjamins.

Zambrano, M. (1973). El hombre y lo divino. México: Fondo de Cultura Económica.

Zweig, S. (2007). El misterio de la creación artística. Madrid: Sequitur. 
Oriol Vaz-Romero Trueba: Doctor en Bellas Artes (Universidad de Barcelona). Doctor en Ciencias de la Educación (Université Paris-XIII).

Contact Address: PULCHRUM: Grupo de Innovación docente en los talleres de Bellas Artes: tradición y contemporaneidad (Vicerrectorado de Política Docente, Universidad de Barcelona). // BRAC, Grupo de investigación consolidado (Generalitat de Catalunya). c/ Pau Gargallo 4. 08028 Barcelona.

E-mail address: ovaztrueba@gmail.com 